\title{
'The legend you thought you knew': text and screen representations of Puteri Gunung Ledang
}

\author{
Mulaika Hijjas
}

Abstract: This article traces the evolution of narratives about the supernatural woman said to live on Gunung Ledang, from oral folklore to sixteenth-century courtly texts to contemporary films. In all her instantiations, the figure of Puteri Gunung Ledang can be interpreted in relation to the legitimation of the state, with the folklore preserving her most archaic incarnation as a chthonic deity essential to the maintenance of the ruling dynasty. By the time of the Sejarah Melayu and Hikayat Hang Tuah, two of the most important classical texts of Malay literature, the myth of Puteri Gunung Ledang had been desacralized. Nevertheless, a vestigial sense of her importance to the sultanate of Melaka remains. The first Malaysian film that takes her as its subject, Puteri Gunung Ledang (S. Roomai Noor, 1961), is remarkably faithful to the style and substance of the traditional texts, even as it reworks the political message to suit its own time. The second film, Puteri Gunung Ledang (Saw Teong Hin, 2004), again exemplifies the ideology of its era, depoliticizing the source material even as it purveys Barisan Nasional ideology.

Keywords: myth; invention of tradition; Malay literature; Malaysian cinema

Author details: Mulaika Hijjas is a British Academy Postdoctoral Fellow in the Department of South East Asia, SOAS, Thornhaugh Street, Russell Square, London WC1H 0XG, UK. E-mail: mh86@soas.ac.uk.

Gunung Ledang rises 1,276 metres out of the surrounding flat land that is now mostly planted with monotonous rows of oil palm in the southern Malaysian state of Johor. Its topographical distinctiveness and relative proximity to the royal city of Melaka mean that, since at least the sixteenth century, Gunung Ledang has been the focus of a dynastic 
legitimation myth linking the maritime state to the powers of the mountain. Literary texts produced after the fall of the Melaka sultanate, the polity that still figures in contemporary Malaysian discourse as the golden age of Malay power and glory, and a chronicle compiled by the conquering Portuguese, as well as oral accounts that have made their way into the written record, tell of a princess living on the mountain. She has no name other than that of the mountain itself, is said to be endowed with the ability to change her age and appearance, to be attended by tigers and to be immortal. To these representations of the princess [puteri] of Gunung Ledang in two of the most canonical texts of traditional Malay literature, Sejarah Melayu and Hikayat Hang Tuah, and in Godinho de Eredia's Description of Malacca, must also be added the depictions of her in two Malay films that take the old Malay texts as source material. Both films are entitled simply Puteri Gunung Ledang, but while the one from 1961 stays close to Sejarah Melayu not only in content but also in style, the film from 2004 wears this heritage lightly and seeks rather to present itself as a lavish epic with global appeal. Nevertheless, the traditional texts and contemporary films alike, more or less unwittingly as the case may be, can be analysed in terms of their attitude to the legitimacy of the state, with the princess on the mountain at their centre.

The significance of the mountain in South East Asian polities has long been recognized. 'As the universe, according to Brahmin and Buddhist ideas,' Heine-Geldern writes in his classic study of kingship in the region, 'centers around Mount Meru, so that smaller universe, the empire, was bound to have a Mount Meru in the center of its capital which would be if not in the county's geographical, at least in its magic center'. ${ }^{1}$ That Melaka, Muslim since the fifteenth century, might yet harbour such ideas should be no surprise, considering that in seventeenth-century Aceh, the so-called 'veranda of Mecca', the palace grounds featured an artificial magic mountain. ${ }^{2}$ The supernatural woman born from the earth or the water, meanwhile, was another recurring feature of dynastic myths in the region. The Cambodian king said to have 'nightly cohabited with the serpent goddess of the soil,' according to Heine-Geldern, 'formed a real magic center linking the empire to the divine forces of the heavens as well as of the earth. ${ }^{3}$ As we will

Robert Heine-Geldern (1956), Conceptions of State and Kingship in Southeast Asia, Cornell Southeast Asia Program, Ithaca, NY, p 3.

Robert Wessing (1988), 'The Gunongan in Banda Aceh, Indonesia: Agni's fire in Allah's paradise?' Archipel, Vol 35, pp 157-194, esp pp 168-170.

Heine-Geldern, supra note 1 , at $\mathrm{p} 10$. 
see, the sultans Yogyakarta and Solo also claimed to have had intercourse with the Goddess of the Southern Ocean, Ratu Kidul, 'the indigenous goddess who under Hindu-Buddhist influences was promoted and given a role as the sakti [sacred power] of deified Javanese rulers' ${ }^{4}$ The Malay court chronicles often trace the origins of the dynasty to the union of a man descended either from such luminaries as Alexander the Great from the lands above the winds or directly from heaven itself and a woman born from river foam or bamboo shoots. ${ }^{5}$ Widespread and potent as this myth may have been, by the time of Sejarah Melayu and Hikayat Hang Tuah, it seems to have been increasingly emptied of its sacred qualities, probably under the influence of Islam. When telling of the mythic events on Bukit Seguntang that established the Melaka lineage, the narrator of Sejarah Melayu provides the reflexive disclaimer 'wa Allahu 'alam,' 'and Allah knows [the truth]' ${ }^{6}$ Beginning with an analysis of Puteri Gunung Ledang's mythic significance as suggested in folklore recorded in written accounts, including de Eredia's Description of Malaca, we pass to the desacralized but still persistent and politically meaningful stories about her in the Malay court texts and thence to the two filmic representations of her - those of 1961 and 2004. Perhaps surprisingly, the 1961 film is closer to the court works than it is to the 2004 film. Whereas the 1961 film cleaved quite closely to the traditional Malay texts, applying the latter's concern with the social contract between ruler and ruled to a new political situation, the 2004 film is both desacralized and depoliticized. The voice-over for the English-language trailer of the 2004 film announces that this is not 'the legend you thought you knew'. Later, the viewer is promised a tale of the 'legendary love' between Puteri Gunung Ledang and the great hero Hang Tuah, a relationship not in fact the stuff of legend, but entirely the innovation of the screenwriters - one of a number of moves that distance the latest film from its purported source material. This process of first emptying a myth of sacred qualities and then of political meaning is doubtless not unusual, especially as in the case of Puteri Gunung Ledang it has taken place over such a long span of time. As we will see, however, the

4 Roy E. Jordaan (1997), 'Tara and Nyai Lara Kidul: images of the divine feminine in Java', Asian Folkore Studies, Vol 57, p 301.

5 For a discussion of Malay dynastic origin myths, see Vladimir Braginsky (2004), The Heritage of Traditional Malay Literature, KITLV Press, Leiden, pp 188, 453456.

6 A. Samad Ahmad, ed (1979), Sulalatus Salatin (Sejarah Melayu), Dewan Bahasa dan Pustaka, Kuala Lumpur, p 39. 
depoliticization of Puteri Gunung Ledang is particularly piquant because it is in direct proportion to the proximity of the filmmakers to the Malaysian political establishment.

Legends - or myths stripped of their sacred meaning - are a notable feature of Malaysian cultural discourse. Lacking a corresponding Malay word, the Anglicism lagenda - so new that there is some doubt about whether it should be pronounced with a hard or soft ' $g$ ' - has become rather ubiquitous as a name for restaurants, resorts and housing developments. Needless to say, lagenda can still wield symbolic power. Hang Tuah (of whom more later) is the most popular and controversial lagenda hero, a lightning-rod for disputes about the highly charged question of allegiance to authority. ${ }^{7}$ But the most incongruously well known lagenda in Malaysia, and a prime example of the ideological valence of such narratives, must surely be that of Mahsuri. As the 'legend' has it, Mahsuri was a beautiful and pure young woman who lived on the island of Langkawi. Happily married to Wan Derus, she was accused by her mother-in-law of adultery with an itinerant storyteller lodging in her parents' house. Despite her protestations, Mahsuri is executed - in some versions, in a particularly gruesome way, impaled from the anus to the stomach. The white blood she sheds on the earth is proof of her innocence and of the efficacy of her curse that Langkawi should become a wasteland, "padang jarak padang tekukur's for seven (or sometimes eight) generations. Her prophecy is fulfilled when the Siamese invade Langkawi, carry out a scorched earth policy and dispense a grim comeuppance to her mother-in-law. This legend is furnished with a landmark that may be visited by tourists: Mahsuri's grave, complete with bilingual commemorative stone tablet bearing a considerably sanitized version of the story. ${ }^{9}$ Why, one wonders, has this deeply unpleasant legend been so enthusiastically publicized?

7 For a review of the Jebat-Tuah controversy and related literature, see Chapter 2 in Khoo Gaik Cheng (2006), Reclaiming Adat: Contemporary Malaysian Film and Literature, University of British Columbia Press, Vancouver, pp 22-55. Previous scholarly articles on the subject are listed in Monique Zaini-Lajoubert (2007), 'Oeuvres malaises modernes inspirées de traditions anciennes (depuis les années 1940)', Archipel, Vol 73, p 195. In brief, Hang Tuah kills his childhood friend Hang Jebat, on the sultan's orders, though Hang Jebat had rebelled against the sultan in Hang Tuah's cause.

8 Translated as 'a plain where the castor oil plant grows and where the turtle doves dwell; a typically desolate place', in R. J. Wilkinson (1903), A Malay English Dictionary, Kelly \& Walsh Ltd, Singapore, p 444.

9 For an image of this commemorative inscription and a comprehensive version of the Mahsuri legend, see Website: http://ms.wikipedia.org/wiki/Mahsuri (accessed 17 April 2009). 
Other than the fact that tourists are thought to like colourful local stories, the answer - one that sheds light on the value of lagenda in contemporary Malaysian culture - lies in Mahsuri's curse and, more specifically, the implication that it was brought to an end by former Prime Minister Mahathir Mohamad. Conveniently enough, the seven (or eight) generations can be calculated to run out some time in the 1980s; Mahathir became Prime Minister in 1981. From Kedah himself, the state to which Mahsuri's home island belongs, Mahathir made the development of Langkawi one of his showcase projects. The island rejoices in duty-free status and attracts some two million tourists a year. Out with the padang jarak padang tekukur, in with the malls and all-inclusive resorts. Needless to say, the subtext of the Mahsuri legend - that the unjust murder of an innocent calls down destruction on the state - is not of particular interest to Barisan Nasional's relentless quest for 'traditional' material to adorn and legitimize its reign. Other examples of this valorization of symbols from the archaic Malay past include, inter alia, the recurring tussles over Hang Tuah, the brandishing of a keris in the 2005 UMNO General Assembly by the then head of the youth wing of the party, and the constant and often malapropic quotations of classical literature in the speeches of cabinet ministers. That heritage and legend are of such interest to the state is no surprise. The invention of tradition has long been recognized as going hand-in-hand with nationalism. ${ }^{10}$ It is within this context of tradition and its reappropriation, and the relationship between that tradition and state legitimation, that the figure of Puteri Gunung Ledang will be read.

\section{'According to the story of the Malaios': folkloric versions}

Oral or folkloric forms are almost by definition absent from the European historical record of South East Asia, except for those rare occurrences when they are recorded as such in written accounts. One such instance is the legend of Puteri Gunung Ledang in the 1613 Portuguese Description of Malacca. The author, Godinho de Eredia, evidently considered 'Gunoledam' to be sufficiently worthy of note to dedicate a chapter to it (other chapters treat more predictable subjects

10 Eric Hobsbawm and Terence Ranger, eds (2003 [1983]), The Invention of Tradition, Cambridge University Press, Cambridge, pp 6-7. 
such as 'antiquities', 'flora', 'fauna', 'fortresses', 'boats' and 'the temperate climate'). ${ }^{11}$ 'To the mountain,' de Eredia explains,

'(according to the story of the Malaios) retired the Queen Putry, companion of Permicuri, founder of Malaca: here the enchanted Putry remains for ever immortal and here she lives to this day by her magic arts.

She makes her home in a cavernous cave on the summit of the mountain, and here she lies on a raised couch decorated with dead men's bones: she takes the form of a beautiful young girl, adorned with silk and gold.

Round about this cavernous cave are planted thickets of bamboo, from which proceed harmonious voices and sounds of flutes and other musical instruments, like the music of tambourines in the Desert of Lob, mentioned by Marco Polo the Venetian. . .

Some distance away from the cave and the bamboos are groves of trees bearing delicious fruits of every kind; here are heard the harmonious songs of birds.

Farther away from this grove are the forests occupied by tigers who guard the Queen Putry, enchanted like another Syrce or the Thessalian.

This story must be a fairy-tale: but the natives regard it as true... ${ }^{12}$

De Eredia's purpose in including these details in his narrative is as an example of the credulity of the natives and, at the same time, contradictorily enough, as an example of a real danger that may be warded off by the spiritual power of the Catholic Church. For he goes on to relate how 'wild Banuas from the interior', followers of the princess, transformed themselves into tigers and attacked the women and children of Melaka. Fortunately, the prayers and threats of excommunication issued by the first Bishop of Melaka served to drive away these weretigers, thereby also effecting the conversion to Catholicism of numerous 'idolatrous natives'. ${ }^{13}$ Noting this polemical intent, it is nevertheless significant that de Eredia seems to have used oral sources to put together his account: while 'according to the story of the Malaios' may imply either written texts or oral reports, that 'the natives regard it as

11 J. V. Mills, trans (1997 [1930]), Eredia's Description of Malaca, Meridional India, and Cathay, MBRAS, Kuala Lumpur, p 15.

Mills, supra note 11, at pp 40-41.

Mills, supra note 11 , at p 41 . 
true' suggests that he is claiming to base his text on the testimony of contemporary local interlocutors. Indeed, de Eredia may have heard these tales in his own home, for his mother was from Makassar in Sulawesi and he spent his childhood in Melaka.

While there are certainly details in de Eredia's account that come from European mythology and travellers' tales (hence the references to Syrce and Marco Polo), it refers to a stable collection of motifs related to the princess of Gunung Ledang. The most notable of these is the association between a supernatural woman living on Gunung Ledang and the Melaka dynasty. This association is made more explicit by de Eredia's identification of the princess as the widow of 'Permicuri, founder of Malaca'. ${ }^{14}$ Second, the princess is allied with the Benuas, an aboriginal people and, third, she can transform herself and others, including turning humans into tigers. Many of these motifs can be found in other oral accounts that have made their way into the written record: her association with tigers (and cats), according to the 'Dato' of Johol', in the Malay state of Negeri Sembilan, in $1891 ; ;^{15}$ her ability to change her age, according to 'an essay written by a Malacca Chinese boy' in $1899 ;{ }^{16}$ and the fact that she lives in a cave attended by Benuas (here no longer people, but 'spirits of the air'), according to inhabitants of villages at the foot of the mountain in 1912. ${ }^{17}$ Skeat's Malay Magic contains numerous stories - collected by Skeat and others, but with no details about their informants - about Puteri Gunung Ledang, noting that she is said to have moved after the fall of Melaka to Bukit Jugra in Selangor. ${ }^{18}$ Like Gunung Ledang, Bukit Jugra is an isolated mountain surrounded by flat land, close to and strongly associated with a royal centre (Klang, the seat of the Selangor royal family, in the case of Bukit Jugra). Both locations were (and are) used for ascetic practices. ${ }^{19}$

In this folkloric material taken as a whole, then, the princess of Gunung Ledang has a typical group of associations: with the mountain, the adjacent royal house, tigers and non-Muslim indigenous people. She can change her age and appearance at will. She has, moreover, both benign and malign aspects: under the former she may, for instance, bestow

14 Sic. 'Permaisuri' is the Malayized feminine form of the 'parameswara' or overlord (Sanskrit: paramesvara), the name given to Melaka's first ruler.

M. L. (1891), 'The Putri of Mount Ophir', JSBRAS, Vol 24, p 165.

R. J. Wilkinson (1899), 'The Putri Gunong Ledang', JSBRAS, Vol 32, p 213.

Mildred E. Staley (1912), 'Mount Ophir legends', JSBRAS, Vol 62, p 24.

Walter William Skeat (1900), Malay Magic, Macmillan and Co, London, pp 71, 164.

Skeat, supra note 18 , at p 71. 
riches on those who help her while she is in the guise of an old woman, ${ }^{20}$ while under the latter she may inflict death. One story recorded by Skeat relates that she was a princess of Melaka travelling in a boat with her husband, a certain Nakhoda Ragam, whom she murdered by pricking him with a needle. The boat filled with his blood, but when questioned by passengers from a passing vessel, she answered that it was only 'spinach juice [kuah bayam]'. Eventually, she landed on Bukit Jugra, where she buried her husband's thigh (all that remained of him). 'She also took ashore her two cats, which were in the boat with her, and which, turning into ghost tigers, became the guardians of this most famous shrine. ${ }^{21}$ This double aspect, at once bloodthirsty and nurturing, provides a clue as to the possible mythic origins of what by the seventeenth century had dwindled to a mere folk tale (in court texts, at least). Puteri Gunung Ledang may be the Malay analogue to the much better studied Ratu Kidul, said to be the queen of the Southern Ocean, where she lives in a palace under the sea. Some accounts of her origin cast her as a princess 'who is exiled from the court and banished to the forest' $^{22}$ (the similarities with Puteri Gunung Ledang in Hikayat Hang Tuah will be evident below). Another casts her as a princess of Pajajaran who goes into exile in the forest when her kingdom is defeated by the forces of Islam. The rest of the court, meanwhile, is transformed into 'spirit-tigers'. ${ }^{23}$ Although Ratu Kidul often appears as an old woman, she is able to rejuvenate at will, and 'as a virgin, marries successive Javanese rulers'. ${ }^{24}$ In the Javanese court chronicle Babad Tanah Jawi, Ratu Kidul is the 'king-maker' through whom Senapati establishes the Mataram dynasty in the sixteenth century: successor kingdoms to Mataram, extending at least as recently as Sultan Hamengkobuwono IX of Yogyakarta (r 1940-88), claimed an alliance with Ratu Kidul. ${ }^{25}$ Ratu Kidul's 'ambiguous nature, her connections with the underworld, her power over life and death, and her position as the source of wealth and prosperity'26 - but especially her role as patron of the ruling house - give her much in common with Puteri Gunung Ledang.

20 For her benign aspect, see M. L., supra note 15, at p 25, and Wilkinson, supra note 16 , at $\mathrm{p} 165$.

21 Skeat, supra note 18 , at p 166.

22 Robert Wessing (1997), 'A princess from Sunda: some aspects of Nyai Roro Kidul', Asian Folklore Studies, Vol 56, p 320.

23 Wessing, supra note 22, at p 320.

24 Jordaan, supra note 4 , at p 300.

25 Jordaan (1984), 'The mystery of Nyai Lara Kidul, Goddess of the Southern Ocean', Archipel, Vol 28, pp 99-100.

26 Wessing, supra note 22, at p 320. 
Ultimately, both Puteri Gunung Ledang and Ratu Kidul may originally have been indigenous chthonic deities who became associated with the Hindu goddesses Durga and Kali and/or the Tantric Buddhist goddess Tara, all of whom are at once malevolent and protective, and who may have been the foci of royal cults in South East Asia. ${ }^{27}$ Although the question of which Indian goddess should be identified as lending her attributes to her South East Asian counterparts is complex and cannot detain us here, the broad outlines are clear enough. The folk tale in which Puteri Gunung Ledang sits in a boat awash with her husband's blood recalls Kali and Durga astride the corpses of their husbands. These goddesses are also often depicted garlanded in skulls and severed arms, recalling the dismembered body of Nakhoda Ragam in the same folk tale, as well as the 'dead men's bones' that de Eredia reported decorated Puteri Gunung Ledang's 'couch'. As we will see below, Sejarah Melayu too notes that her resting place is furnished with bones and thatched with human hair. Her demand for a dish of human blood in that text also makes sense if she is considered as a sister to Kali, Durga and Tara. These goddesses, again, typically dwell outside the pale of human civilization, in caves, forests and other wild places. In this context, the Benua who are mentioned so often in connection with Puteri Gunung Ledang may be read not as any real indigenous group of the Malay peninsula, but as those backsliding Muslims - or perhaps outright heathens - who persist in their devotion to an undeniably pagan deity. The folkloric material, from de Eredia in the early seventeenth century to the stories collected by British colonial administrators at the beginning of the twentieth century, may preserve a distant and desacralized memory of Tantric goddess worship, crucially tied to kingship, in the form of Puteri Gunung Ledang. Although the Malay court texts discussed next make no explicit mention of Puteri Gunung Ledang's intimate connection to the state, they seem nonetheless unable to leave her entirely out of the story of the dynasty's rise and fall.

\section{Puteri Gunung Ledang in the traditional Malay canon: Sejarah Melayu and Hikayat Hang Tuah}

Among the most important works of Malay manuscript culture - the

27 Another supernatural princess associated with a mountain in folklore is Puteri Santubong in Sarawak. Santubong is an area rich in archaeological finds, including a statue of a 'seated divinity' that may be Tara. See Tom Harrisson and Stanley J. O'Connor Jr (1967), 'The “Tantric Shrine” excavated at Santubong', Sarawak Museum Journal, Vol 15, p 213. 
literature produced in the Malay language and written in the Jawi script in court centres across the Malay world, roughly from the thirteenth to the nineteenth centuries - are the chronicle known as Sejarah Melayu and the heroic romance Hikayat Hang Tuah. Their significance stems not only from the fact that they deal with the most glorious epoch of Malay history, the Melaka sultanate, but also because they are remarkable and foundational artistic achievements. Both mention Puteri Gunung Ledang and, although the stories they tell about her are quite different, both hint at her significance to the enduring reign of the Melaka sultans. Sejarah Melayu [The Malay Annals] tells, as Vladimir Braginsky writes, 'the mysterious story of Malacca's rapid rise and its sudden fall'.$^{28}$ In his view, the earliest recension dates to about 1536 and was probably carried out by someone of the Bendahara family, the lineage that had provided Melaka with its chief ministers. ${ }^{29}$ In the initial part of Sejarah Melayu, as already noted, two scions of Alexander the Great appear upon a Sumatran mountain. Their descendants go on to found Melaka. The chronicle's overarching theme, to which all its component parts subtly contribute, is the social contract between ruler and ruled as the foundation and condition of Melaka's greatness. This contract means that the subjects will never rebel against their ruler, so long as the ruler never humiliates his subjects. ${ }^{30}$ Much of the text is comprised of what Braginsky terms novellas:

'carefully selected stories which are written with graphically visual clarity ... As a rule [these stories] are more lengthy in the first half of the chronicle, more traditional and contain more loci communes and legendary motifs, while in the second part, particularly in the chapters about the rule of Sultan Alauddin and Sultan Mahmud Syah, the stories become shorter and reflect the chronicler's artistic individuality in a more sharply defined way. ${ }^{31}$

It is all the more remarkable, then, that the episode about Puteri Gunung Ledang occurs in the latter part of the text, otherwise given up to wry

28 Braginsky, supra note 5, at p 187.

29 Braginsky, supra note 5, at pp 92-103. Here, Braginsky concurs with the view of R.O. Winstedt (1938), 'The Malay Annals or Sejarah Melayu', Journal of the Malayan Branch of the Royal Asiatic Society, Vol 16, No 3, pp 1-225.

30 Braginsky, supra note 5, at pp 188-189; R.O. Winstedt (1996), A History of Classical Malay Literature (reprint), MBRAS, Kuala Lumpur, p 57; Ahmad, supra note 6, at p 24.

31 Braginsky, supra note 5, at p 191. 
vignettes about notable characters of the chronicler's time and of course to the events surrounding the fall of the city. As we shall see, the reason why this mythic character appears in the non-mythic (albeit glittering) Melaka that the chronicler himself knew so intimately may well be because she has a role to play in explaining the end of the dynasty.

In Sejarah Melayu, Sultan Mahmud of Melaka, a widower, decides to ask for the hand of Puteri Gunung Ledang, rather than any common or garden princess: 'what we desire is that which no other raja possesses, that is the one we wish to take to wife'. ${ }^{32}$ The sultan dispatches his trusted Laksamana, Hang Tuah, accompanied by one Sang Setia, to woo the princess. Their retinue includes a corps of men from Inderagiri, led by Tun Mamad and a Benua man named Dendang Anak to show them the way. (Although Dendang Anak is never mentioned again, the presence of a nonMuslim 'tribal' man is a significant constant in narratives about Puteri Gunung Ledang.) Finding the way hard going and hindered by a strong wind, the party stops halfway up the mountain, with Tun Mamad volunteering to carry on with two attendants. Battling the wind, they ascend into the cloud cover and then find themselves in a magical garden full of flowers, fruit, animals and birds. The birds and flowers sing, exchanging allusive pantun verses. In the centre of the garden, Tun Mamad comes across a pavilion, all of its furnishings made of bone and its thatch of human hair, where a 'well-formed' old woman sits with four young women attending her. When the old woman questions him, he informs her of his mission. She declares that she will take the sultan's message to the princess, and disappears with her attendants. A moment later, an old, hunchbacked woman appears, with the following message from the princess:

'If the Melaka raja desires me, make me a bridge of gold and a bridge of silver, from Melaka here to Gunung Ledang. As wedding gifts [give me] seven platters of mosquito hearts, seven platters of lice hearts, a jar of tears, a jar of the juice of young areca nuts, and a cup of the blood of the prince named Raja Ahmad. If these are [presented], the princess will fulfil the Melaka raja's desire. ${ }^{33}$

32 'Yang kita kehendaki barang yang tiada pada raja-raja yang lain, itulah yang hendak kita peristerikan', Ahmad, supra note 6, at p 199. (Translations mine unless otherwise noted.)

33 'Jikalau raja Melaka hendakkan aku, perbuatkanlah aku jambatan emas satu dan jambatan perak satu, dari Melaka datang ke Gunung Ledang ini. Akan peminangnya hati nyamuk tujuh dulang; hati kuman tujuh dulang; air mata setempayan; air pinang muda setempayan; darah anak raja yang bernama Raja Ahmad itu semangkuk. Jikalau ada demikian kabullah tuan puteri akan kehendak Raja Melaka itu', supra note 6, at p 201. 
Some accounts say, Sejarah Melayu notes, that this was Puteri Gunung Ledang herself, in the shape of an old woman. Tun Mamad duly returns to his companions, and from thence the party proceeds to Melaka. The sultan responds to the princess' conditions by saying that: 'All those wishes of hers we can fulfil, [but as for] draining the blood of our son, what can we do, for we have not the heart'. ${ }^{34}$

The Puteri Gunung Ledang episode is succintly told in Sejarah Melayu, covering only five or so manuscript pages, and its point is clearly made. The sultan, primus inter pares in the Malay world, desires the rarest, least attainable woman known to him. She sets him outlandish conditions that would be impossible for any lesser man, but such is the wealth and power at his command that he is able to fulfil all of them - except the last, killing Raja Ahmad, his son and heir. It is not a question of inability to fulfil the condition, but of a refusal to rupture the familial bond. The sultan's rebuttal is therefore a sign of his righteousness. He is no monster: faced with the choice between marriage to Puteri Gunung Ledang and the life of son, he does not hesitate. Sultan Mahmud's moral compass here is particularly noteworthy because Sejarah Melayu does not shirk from portraying his failings. Throughout the text, Sultan Mahmud is depicted as a man with a weak grip on his passions, in traditional Malay discourse a sure sign of being unfit to rule and of imminent disaster for the state. Sultan Mahmud's greatest weakness is for women, leading directly to his violation of the crucial contract with his subjects. Returning from a night with the wife of Tun Biajid, Hang Tuah's son, Sultan Mahmud encounters the husband he has just cuckolded. Tun Biajid, armed and accompanied by his followers, weighs his spear in his hand and tells the sultan that were he, Tun Biajid, not a Malay who had sworn an oath of loyalty to the sultan, he would launch the weapon into the sultan's chest. With remarkable sangfroid, Sultan Mahmud tells Tun Biajid's irate followers: 'those words of his are true, we are certainly in the wrong towards him; by law we ought to be killed by him, [but] as he is a Malay subject he does not wish to commit treason and so he acts thus'. ${ }^{35}$ Later, Sultan Mahmud sends Hang Nadim to Pahang to abduct Tun Teja, betrothed to the Sultan of Pahang, provoking war with that state. ${ }^{36}$ Most disastrously, he orders the

34 'Semua kehendaknya itu, dapat kita adakan; mengeluarkan darah anak kita itu juga apatah daya; kerana tiada sampai hati kita', Ahmad, supra note 6, at p 201.

35 'Katanya itu benar, kita sedia salah kepadanya; pada hukumnya patut kita dibunuhnya, daripada ia hamba Melayu, tiada ia mau derhaka, maka demikian lakunya', Ahmad, supra note 6 , at $\mathrm{p} 181$.

36 Ahmad supra note 6, at pp 210-220. 
annihilation of the Bendahara clan in order to take for himself Tun Fatimah, the Bendahara's daughter, already married to Tun Ali. ${ }^{37}$ In all these instances, the sultan's lust undermines the pillars of the state. The chronicle intimates that the Portuguese attack was but the final blow to the worm-eaten structure of the Melaka royal house. Why then does the text show him declining an act of bloodshed and thereby giving up his pursuit of Puteri Gunung Ledang?

Interpreting Puteri Gunung Ledang in Sejarah Melayu is complicated by the fact that, like many premodern texts, it exists in several distinct versions or recensions, each with their own particular histories and biases. Two recensions of Sejarah Melayu connect two different sultans with this attempt to marry Puteri Gunung Ledang. This was noted by the colonial adminstrator-scholar Winstedt, who believed that the original author had probably lived during Sultan Mahmud's time and so "could not possibly ascribe to that ruler the fool errand of wooing the fairy princess of Mount Ophir'. Instead, in Winstedt's view, the recension that paired Puteri Gunung Ledang with Sultan Mahmud (14881528) dates from a later period than that which paired her with Sultan Mahmud's grandfather Sultan Mansur (1459-77). ${ }^{38}$ While Winstedt is probably right about the relative ages of the recensions, with the Sultan Mansur version belonging to the earlier Melaka recension and the Sultan Mahmud version belonging to the later Johor recension, ${ }^{39}$ his dismissal of the Puteri Gunung Ledang element as mere foolish fairytale is too hasty. The marriage between a king and a supernatural female figure associated with the earth or the sea is, as already noted, foundational to the legitimacy of the polity. In the older recension, then, the association between Puteri Gunung Ledang and Sultan Mansur, the ruler who presided over the flourishing of Melaka, is not motivated by the author or redactor's fanciful whimsy. Nor is the assignment of the story about Puteri Gunung Ledang to Sultan Mansur or Sultan Mahmud a matter of copyist error or bias. These two rulers presided over Melaka's rise and its fall respectively. That Sultan Mahmud does not marry her may presage the end of his rule: he did not achieve the symbolic union with the supernatural or semi-divine female figure that

37 Ahmad, supra note 6, at pp 240-244.

38 Winstedt, supra note 30, at p 111. Winstedt's hypothesis is rejected by A. Samad Ahmad in the concluding remarks to his edition of the text, pp 299-301. A. Samad Ahmad believes, rather, that the pairing of Sultan Mansur and Puteri Gunung Ledang was an attempt by the copyist employed by the colonial philologist Blagden to besmirch the name of Sultan Mansur!

39 See Braginsky, supra note 5, at p 103. 
the pre-Islamic polity demanded, and at the same time, his failure to master his passions meant that he destroyed the social contract that underpinned the Malay-Muslim state.

Hikayat Hang Tuah is not a chronicle, but a 'tale', a narrative that would have been regarded by its author and original audience as fiction (which would not, of course, preclude edifying messages intended by that author and absorbed by that audience). The rise and fall of Melaka takes place within the lifetime of a single king, straightforwardly enough named Raja Melaka, who relies upon the ever loyal hero Hang Tuah. Gunung Ledang is mentioned early on in the narrative as the place where the king, as a result of certain auspicious signs, founds his state, ${ }^{40}$ underscoring the centrality of this place to Melakan royal legitimacy. Later, Puteri Gunung Ledang appears in the story as the eldest child of Raja Melaka and his Javanese queen. Her half-brothers are Sultan Mahmud, who is set up as the ruler of Bentan, and Sultan Muhammad (also referred to as Sultan Ahmad), who is made ruler of Terengganu. ${ }^{41}$ Raja Melaka names Puteri Gunung Ledang as his heir. Although female succession was not unknown in the Malay world, its occurrence in this text is not an endorsement of the rule of women, but rather a symptom of the weakening of the state and a portent of its fall. However, Puteri Gunung Ledang does not make too bad a job of government in the beginning, reigning, in the usual formula for just monarchs, 'with justice and generosity towards all her people, and solicitous towards the merchants and religious men who came and went'. ${ }^{42}$

Puteri Gunung Ledang's gender is thematized in the first episode in which she figures. Hearing that the boat carrying her fiancé, Raja Culan, has been sunk by Terengganu forces, she is angered and goes at once to her father and subtly hints that his manhood is impugned by his failure to take revenge. 'My lord, I am like that spoken of in the poem: its name is said but it appears not. That's why I behave in this way. What can I do, for I am a woman? Were I a man, I would know how to settle the matter.' ${ }^{43}$ Her barb hits its mark and Raja Melaka commands Hang

40 Kassim Ahmad, ed (1975), Hikayat Hang Tuah, Dewan Bahasa dan Pustaka, Kuala Lumpur, p 58.

41 Kassim Ahmad, supra note 40, at pp 424 and 439.

42 'Tetap di atas kerajaannya dengan adilnya dan murahnya akan segala rakyat dan dagang senteri yang pergi datang itu sangat tafahusnya', Kassim Ahmad, supra note 40 , at p 520 .

43 'Ya tuanku, patik ini adalah seperti pantun orang: namanya ada disebut, rupanya tiada. Akan patik ini pun demikian laku. Apatah daya patik perempuan. Jika patik laki-laki, tahulah patik membicarakan dia.' Kassim Ahmad, supra note 40, at p 437. 
Tuah to attack Terengganu. It may be intended as a sign of Raja Melaka's declining ability to rule that he has to be goaded into action by his daughter. In any case, Puteri Gunung Ledang's inherent weakness as a woman - which, ironically enough, she herself invokes in this instance in order to get her way - crops up again when she is next mentioned in the text. Raja Melaka commands his courtiers to go to Rum (Istanbul) and obtain cannons and shot to protect a state governed by a woman more effectively. Once Hang Tuah has returned with the cannons, after sundry adventures in the lands above the winds, Puteri Gunung Ledang is installed as raja, and Melaka is fortified. As the text piously opines, foreshadowing the coming defeat, 'Thus it is with a country that Allah the Most High intends to destroy, which no creature can know of [in advance]; that which should not be done by the calculations of the intelligent is carried out by the arrogant. ${ }^{44}$ The Portuguese arrive and offer to pay fabulous sums for as much land as can be covered by a cattle-hide. Puteri Gunung Ledang follows the advice of her ministers and grants the Portuguese request, but the dastardly Europeans turn the hide into a rope and fence off a huge plot of land, on which they build a storehouse. It is from this building that they launch a surprise attack and take over the city.

Only once the Melakans flee from the Portuguese bombardment of the city into the surrounding hinterlands - just when her story comes to an abrupt end - can the Puteri Gunung Ledang of Hikayat Hang Tuah be connected to that of Sejarah Melayu. Together with her attendants and ladies-in-waiting, she flees upriver, 10 days' journey into the interior. 'Then Putri Gunung Ledang fell into an immense jungle near the country of the Batak. She was taken by the Batak ministers and made raja of Batak country. And nothing further is to be said of Puteri Gunung Ledang to this day. ${ }^{45}$ Here at last are familiar elements: the exclusively female retinue that attends the princess in the wilderness (another feature she shares with Ratu Kidul) and her association with the nonMuslim peoples of the interior (although of course the Batak are a Sumatran rather than a Peninsular ethnic group, here they obviously

44 'Demikianlah negeri yang hendak dibinasakan Allah Taala itu, tiada dapat segala makhluk mengetahui; yang tiada patut dengan ahlulkira-kira itu dikerjakan oleh segala yang takbur.' Kassim Ahmad, supra note 40, at p 513.

45 'Maka Putri Gunung Ledang pun jatuh ke dalam hutan rimba yang amat besar hampir dengan negeri Batak. Maka diambil oleh segala menteri Batak itu, dirajakannya Putri Gunung Ledang itu dalam negeri Batak itu. Maka tiadalah tersebut lagi perkataan Putri Gunung Ledang itu hingga datang sekarang ini.' Kassim Ahmad, supra note 40 , at pp 522-523. 
stand for a generic 'pagan' other to the text's Malay author and audience). It is obvious that, in comparison with Javanese texts such as Babad Tanah Jawi, in which Ratu Kidul's role as kingmaker and dynastic legitimator is stated as a matter of course, Puteri Gunung Ledang in the far more selfconsciously Islamic Sejarah Melayu and Hikayat Hang Tuah is a vestigial figure, a once potent deity turned fairytale character. That she nevertheless is mentioned, and especially that the stories about her occur in such unexpected places in the texts, suggests that, in spite of her desacralization, there still lingered a sense of her former significance.

\section{Political allegory in a time of emergency}

The 1950s and 60s have been described as the golden age of Malay cinema, with the Cathay-Keris and Shaw brothers-controlled Malay Film Productions studios vying with each other to produce up to 20 films a year. ${ }^{46}$ Many of these productions drew upon traditional Malay texts for their source material. ${ }^{47}$ At least five other films produced in 1961, the year that S. Roomai Noor's Puteri Gunung Ledang appeared, were based on the Malay manuscript tradition: Hang Jebat (Hussein Haniff), Panji Semerang (Omar Rojik), Siti Zubaidah (B.N. Rao), Sultan Mahmud Mangkat Dijulang (K.M. Basker) and Yatim Mustaffa (B.N. Rao). ${ }^{48}$ Even as late as the 1960 s and even in the new medium of film, then, the 'traditional' texts and stories still exerted a pull on audiences. Of course, these adaptations tended to stray from the plots and still more so from the spirits of their purported sources. Commenting on Malay literary and film works since 1940, Zaini-Lajoubert notes that twentieth-century writers and filmmakers 'made their appeal to old Malay traditions to explain their own ideas,' having 'recourse to the past for essentially political ends'. ${ }^{49}$ For this reason, the characters from

46 Jan Uhde and Yvonne Ng Uhde (2000), Latent Images: Film in Singapore, Oxford University Press, Singapore, p 9.

47 It seems likely that the films draw on the bangsawan theatrical tradition, which first adapted traditional literary texts for performance. See Rahmah Bujang (1975), Sejarah Perkembangan Drama Bangsawan di Tanah Melayu dan Singapura, Dewan Bahasa dan Pustaka, Kuala Lumpur. For a study of a similar process through which traditional literature influenced film, via stage performance (itself an influence on bangsawan), see Vladimir Braginsky and Anna Suvorova (2008), 'A new wave of Indian inspiration: translations from Urdu in Malay traditional literature and theatre', Indonesia and the Malay World, Vol 108, pp 115-153.

48 For the full list of films produced by year, see Uhde and Uhde, supra note 46, at pp 228-229.

49 Zaini-Lajoubert, supra note 7, at p 195 (my own translation). 
traditional literature most frequently reinterpreted in Malay film, drama and literature are Hang Jebat and Hang Tuah, embodying as they do (or rather, as they are made to do in their modern incarnations) a political argument between obedience to authority and individual morality. S. Roomai Noor's Puteri Gunung Ledang similarly uses the traditional text to advance a thoroughly contemporary political argument. While its mise en scène follows Sejarah Melayu quite closely - complete with anthropomorphized flowers in the princess' enchanted garden uttering pantun and syair - the film's message is one appropriate to 1961 rather than the 1600s.

The film opens with Tun Fatimah teaching songs to children, observed by her brother Tun Zainol. In a neatly gendered dichotomy, she is depicted several times in the course of the film as a conduit of traditional Malay culture in the form of songs and dances, while he is shown to be an exponent of a certain kind of Malay political culture, refusing to submit to unjust authority and rebelling against slights to his dignity. Tun Zainol is, in other words, the Hang Jebat of the film. Their father the Bendahara, meanwhile, stands for loyalty to the sultan above all, echoing the position of Hang Tuah, who is here following Sejarah Melayu, a man grown old in the service of the state. Tun Fatimah is to marry Sultan Mahmud, but the wedding plans are cancelled after Puteri Gunung Ledang appears to him in a dream. Besotted, Sultan Mahmud dispatches Hang Tuah at the head of a party of men including Tun Mamat to Gunung Ledang to ask for her hand. Incensed by the sultan's rejection of his sister, Tun Zainol leads a band of men into the jungle to waylay the mission. He is aided in his covert insurrection by a tribal leader, the Benua Dendang Anak from Sejarah Melayu, transmogrified into a generic barbarian owing more to Hollywood stereotypes of the savage than to any Peninsular orang asli people. ${ }^{50}$ Together, the rebellious noble and the insurrectionary tribals sabotage and ambush Hang Tuah's party. More men are picked off by the natural perils of the mission (snakes, tigers and bears, along with heights). When Hang Tuah falls ill, Tun Mamat volunteers to continue on with a small band of companions. Captured and taken to a tribal village, Tun Mamat and his men are first treated to dances (again, apparently cribbed from Hollywood's idea of Polynesia) and then treacherously attacked. Tun Mamat alone manages to escape and finds himself in the enchanted grove,

50 Malay for 'original people'; the term used in contemporary Malaysia for the indigenous groups of the Peninsula. 
where he is serenaded by but stoutly resists the charms of several female flowers. The influence of the popular bangsawan theatrical form is evident in the solo musical numbers performed by the flowers. An old woman appears, chases off the flowers, and agrees to take his message to the princess. Puteri Gunung Ledang then materializes in clouds of dry ice and issues her conditions, the same as those given in Sejarah Melayu.

Back at base camp, Hang Tuah interprets the princess' list of impossible demands as, in effect, a refusal. Having failed to deliver on his promise to the sultan, Hang Tuah then casts away his sacred kris and abandons himself to the wilderness - a divergence of the 1961 film from the traditional texts that is repeated in the 2004 film. To be sure, in Hikayat Hang Tuah, the hero does end his days in a jungle exile interestingly enough, as king of the biduanda, an orang asli people. ${ }^{51}$ However, this occurs at the very end of the text, after the fall of Melaka. To associate the loss of Melaka's iconic hero with the failure to woo Puteri Gunung Ledang, as the films do, is to emphasize her importance to the maintenance of the state. Tun Mamat and the others return to Melaka and present the princess' demands to Sultan Mahmud. Nothing daunted, the sultan sets the apparatus of the state in motion: women's jewellery is requisitioned to build the bridges of silver and gold, and men are put to work constructing and collecting the other items on the princess' list. Taking advantage of the popular unrest that this tyrannous behaviour produces, Tun Zainol foments a revolt. His exhortations to the common people to rise up against injustice bear little resemblance to the political ideology of the traditional texts: "what is the difference,' he asks rhetorically, 'between a sultan and the people? Nothing, for a sultan is sovereign because of his people'. ${ }^{52}$ Even more strikingly, he argues that there is no difference between a king and a commoner; all are equal. Despite the increasingly restive population and the misgivings of his nobles, Sultan Mahmud presses on until all that remains to be prepared is the blood of his young son. At the sleeping boy's bedside, the sultan is about to do the deed when Puteri Gunung Ledang appears and declares that she would never marry a man so cruel. Her requests are thus revealed as a test that the sultan failed because of his selfishness and inhumanity. Suitably chastised, the sultan abandons his pursuit of her. Meanwhile, the rebellion has reached

52 'Apa bezanya antara sultan dengan rakyatnya? . . . berdaulat sultan kerana rakyatnya.' 
the palace. Although his courtiers implore him not to go down to the rebels, Sultan Mahmud descends to the earth, penitently admits his mistakes to the rebels and begs their mercy. Perhaps as shocked as the chronicler of Sejarah Melayu would have been by such an unprecedented act, Tun Zainol and the rebels lay down their arms at once and raise a cry of 'Daulat Tuanku!' ['God save the King!' - though with intimations of that king's supernatural powers].

The 1961 Puteri Gunung Ledang was filmed at the Cathay-Keris Studios in Singapore, at that time already wielding full internal selfgovernment, with the British retaining control over external relations and some aspects of internal affairs. Audiences of the film on the Peninsula had been citizens - for the first time in history neither feudal nor colonial subjects - only since 1957, a mere four years. This political identity was all the more novel as the independence movement in British Malaya had undergone a relatively short development and had been much focused on the Sultans as talismans of Malay sovereignty. (This is in marked contrast to Indonesia, where the anticolonial movement was also strongly republican and anti-'feudal'.) It is perhaps in this context that the flurry of films based on traditional texts strongly associated with the Malay aristocracy should be understood. On the one hand, films based on these texts clearly resonated with audiences in the 1950s and 60s; on the other, these texts' espousal of allegiance to the throne at all costs would no longer have sat so easily with filmmakers and filmgoers at that time. The kind of polity achieved at the end of Puteri Gunung Ledang is far from that propounded in Hikayat Hang Tuah or Sejarah Melayu; rather, it is a community of equals ruled over by a king who submits to his wise ministers and governs with the welfare of his subjects at heart - in other words, a constitutional monarchy.

The second aspect of the film that strongly reflects its era is the depiction of the jungle and its inhabitants, the orang asli. We have seen that indigenous peoples played a significant role in the myth of the princess of Gunung Ledang in earlier times, perhaps as a marker of her position outside the Malay Muslim symbolic order. It should also be noted that indigenous groups played an important economic role in traditional Malay states. As inhabitants of the interior, they controlled access to lucrative forest products. Up to the present day, orang asli representatives are present at the installations of certain of the Malay sultans. However, during the Emergency (1948-60), the orang asli came to an unprecedented prominence. As the jungle became the battleground 
between the insurgents and government forces, orang asli inhabitants were caught up in the turmoil. They were in demand as guides, porters and providers of food for the Malayan Communist Party forces. An orang asli fighting force, the Senoi Pra'aq, was set up by the government, and villages were resettled so that they were under the watchful eye of government forces. The indigenous peoples bore the brunt of the conflict, suffering many casualties and the uprooting of their way of life. ${ }^{53}$ If this was indeed the first time that many city-dwelling Malayans had even heard of the forest inhabitants of the Peninsula, ${ }^{54}$ this new awareness did not translate to understanding or sympathy. As evidenced by the ferocious jungle men in Puteri Gunung Ledang, Malays evidently did not share the European stereotype of orang asli passivity and pacifism debunked by Leary. In the nineteenth century, Leary reminds us, orang asli were Malays' chief source of slaves - relations between the two communities were always fraught, to say the least. ${ }^{55}$ That the film shows the orang asli to be violent and also under the direction of an outside power, the disaffected nobleman Tun Zainol, accords perfectly with their depiction in the Malayan press as a childlike people who, when they sided with the communists, were deemed either 'terrorist-dominated' or brainwashed by propaganda. ${ }^{56}$ In the 1960s, the jungle was more than ever a place to be feared: little wonder, then, that the film depicts it as a place of danger and its inhabitants as bloodthirsty savages. Yet the demonization of the orang asli in Puteri Gunung Ledang clearly demarcates the limits of the film's vision of Malayan citizenship. The restored polity achieved at the end of the film, with Sultan Mahmud a ruler whose sovereignty exists because of and for his people, is wholly Malay. The orang asli are the only nonMalay group to appear at any point in the film, and they function only as an external threat that is at last banished to the margins. In light of the polemics over the status of non-Malays in independent Malaya that exploded in the opposition to the Malayan Union from 1946 to '48, the film's vision of a racially homogeneous polity can hardly be regarded as innocent.

Significantly, although the 1961 Puteri Gunung Ledang reworks the message of the story about the princess on the mountain, it neverthe-

53 See Tim Harper (1999), The End of Empire and the Making of Malaya, Cambridge University Press, Cambridge, pp 267-273.

54 John D. Leary (1999), Violence and the Dream People: The Orang Asli in the Malayan Emergency, 1948-60, Center for International Studies, Athens, OH, p 1.

55 Leary, supra note 54, at p 18.

56 Leary, supra note 54, at p 184. 
less preserves the idea that she, and the traditional texts as a whole, are deeply concerned with the Malay political contract between ruler and ruled. In reworking the terms of this contract and recasting Malay kingship as, in effect, a constitutional monarchy, the film appropriates the authority of the traditional texts for an entirely modern purpose. Here, of course, there is no longer even a residual notion of sacral kingship sealed by union with a chthonic goddess. Rather, Puteri Gunung Ledang becomes an outside arbiter of Sultan Mahmud's right to rule, testing him and finding him wanting, and thereby reminding him of his duty to the rakyat [the people]. Perhaps it is not too much to read her portrayal by the Eurasian or European actress Elaine Edley, in her cinematic debut, as a stand-in for the continuing British presence in independent Malaya. The fidelity of S. Roomai Noor's film to the story as a political allegory, in spite of the fanciful Hollywood and bangsawan theatrical influences, is in marked contrast to the most recent Puteri Gunung Ledang, in which politics is conspicuously absent.

\section{Bolehwood blockbuster}

Here, the princess is Gusti Puteri Retno Dumilah, the sister of the ruler of the Majapahit kingdom in Java. Having met Hang Tuah while he and the Melaka Sultan were on a mission to her brother's court, she falls in love with him. The film opens with her dream - a burning tree in the centre of a labyrinth - that impels her across the Straits to take up residence on Gunung Ledang. Hang Tuah is shown in a Melaka market, rescuing a young girl from being forced into marriage. 'Love and blessings,' he opines, 'cannot be forced', ${ }^{57}$ thus underlining the theme of the film: the old chestnut of love versus duty. Hearing of his sister's disappearance, the Adipati of Majapahit storms off to Melaka, where he contracts a marriage between her and the Sultan that he also hopes will protect his Hindu-Buddhist kingdom from the expansionist ambitions of Muslim Demak. Sultan Mahmud of Melaka, even more self-indulgent than in previous portrayals, is nothing loath to marry an additional wife, though his son with Tun Teja has just been made crown prince. Hang Tuah is forced to affirm agreement to the match between his lord and his beloved to the assembled court, thus signalling that his devotion remains with the state. Using her supernatural powers, Gusti Puteri communicates with her brother and they dispute the priority of 
the promptings of the heart ['kata hati'] over duty towards their people. She then agrees to marry the Pangeran of Demak in order to save her kingdom, to which her brother accedes (thus, puzzlingly, scotching the just concluded diplomatic mission with Melaka). Sultan Mahmud refuses to accept this slight to his majesty and sends Hang Tuah to tell the Pangeran that Gusti Puteri is still set to be Melaka's queen. He then packs off Hang Tuah, Tun Mamat (here a bit of a toady) et al to Gunung Ledang to press his suit. Supernatural trials directed by the princess hamper the expedition. Disguised as an old woman, Gusti Puteri goes to the men and confirms that her beloved has come on behalf of another. When Hang Tuah and the princess - in her usual form - meet at last, surrounded by a flock of computer-generated images of butterflies, she learns that indeed duty is stronger in him than love. She therefore issues her conditions, although here they are in the form of Javanese riddles that must first be decoded. Hang Tuah understands them as a rejection of Sultan Mahmud's suit and, having failed both his love and his lord, casts away his kris and wanders into the wilderness (though not before defeating the Adipati of Majapahit in a fight involving much flying through the air). Flailing in a mangrove swamp, Hang Tuah has an existential crisis. Back at the court, Sultan Mahmud is about to kill his son, but Gusti Puteri intervenes and tells him that the conditions were indeed a refusal. Hang Tuah is seen running back to Gunung Ledang, where he confesses his love to and begs forgiveness from the princess. She sees and hears him, but does not reveal herself. A mournful voice-over ends the film by announcing that neither Hang Tuah nor the princess was seen again from that day forth. Thus, it would seem, the battle between love and duty ends in a defeat on all sides: the lovers are not united, Hang Tuah fails in his service to the state, and Majapahit is not saved from Demak.

This 2004 Puteri Gunung Ledang was the biggest budget Malaysian movie to that date, costing an estimated US\$4 million or RM20 million. Rumour had it that the money came from the private coffers of Dato' Seri Effendi Norwawi, a Sarawak-based politician, former national Cabinet member, founder of the television station NTV7, and husband of the film's star and producer, Tiara Jacquelina. There are allegations that abuse of ministerial powers may have been involved in securing a location used in the film, a protected forest reserve that was damaged by the shooting. ${ }^{58}$ Despite - or, rather, because of - the film's 
origin in the nexus of power in Malaysia, it is a resolutely depoliticized confection intended as much for the international circuit as for local audiences. Rather than using the sources to address ideas about the individual and the state, as the 1961 film did, Puteri Gunung Ledang of 2004 mines the Malay manuscript tradition in an attempt to fashion the kind of slick cinematic product that places a love story against an exotic backdrop, exemplified by Crouching Tiger, Hidden Dragon (Ang Lee, 2000) and Tristan + Isolde (Kevin Reynolds, 2006). The film's international orientation was admitted by the director, Saw Teong Hin, in an interview with the Bangkok Post: 'The producers knew from the beginning that it' $\mathrm{d}$ be difficult to get the money back, but they went ahead anyway because, first of all, they really wanted to see it happen, and because they decided to go for the international markets, which is something no Malaysian has ever done before' ${ }^{59}$ The impulse to spend large sums of money in pursuit of international recognition is so familiar in Malaysia that the condition has its own name: Bolehism, after the slogan 'Malaysia boleh!' or 'Malaysia can do it!' popularized under Prime Minister Mahathir. Among the mega-projects that populate Bolehwood - to use the term coined by sketch comedy group Instant Café Theatre - are the Petronas Twin Towers, the Sepang Formula One race track, the tallest flagpole in the world on Merdeka Square, and the mission to put a Malaysian in space. ${ }^{60}$ Puteri Gunung Ledang the film of 2004, followed by the musical version of 2006, which declared itself to be 'Malaysia's first attempt to stage its very own West End scale production' ${ }^{61}$ is perfectly at home in this line-up. All these projects are founded on achievement for its own sake, at great cost to the environment and the public purse, in the service of a narcissistic conception of the national interest. In purely commercial terms, the film was not a success, making hardly a ripple on the international circuit and failing to earn back anything near its outlay at the domestic box office. ${ }^{62}$ At the 2005 Malaysian Film Festival, Puteri Gunung Ledang was pipped to the Best Film Award by a small independent film.

59 'Malaysia seeks piece of world box office', 21 January 2005, Website: http:// www.imdb.com/title/tt0420101/news\#ni0095129 (accessed 31 October 2009).

60 Michael Backman (2006), 'While Malaysia fiddles, its opportunities are running dry', The Age, 15 November, Website: http://www.theage.com.au/articles/2006/11/ 14/1163266550487.html (accessed 31 October 2009).

61 See 'Production notes', Website: http://www.pglthemusical.com.my/season_01/ production_note.html (accessed 31 October 2009). The musical will not be discussed further in this article as I was not able to watch it.

62 It reportedly made RM3 million. Amir Hafizi (2005), 'The princess reappears', The Malay Mail, 18 October. 
More significant is the film's artistic failure, or rather its complete lack of ambition towards anything other than grandiose spectacle. The love story between Hang Tuah and Gusti Puteri, bogged down by stolid performances from the actors, is unconvincing and ends, as we have seen, at a dramatically unsatisfying impasse. The conflict between love and duty is left unresolved, with the film unable to depart from the source material and imagine a happy ending for its protagonists in spite of how fast and loose it had played with the traditional texts up to that point. The political allegory that that love story displaced, which was at the heart of previous versions of this narrative, is muddled. So while Sultan Mahmud is shown to be unworthy of anyone's fealty, the film does not depict any consequences of that - either for him or for Melaka. While the Bendahara's declaration that 'everything is for Melaka' ${ }^{6}$ seems to place the state first, above the person of the ruler, slavish loyalty to the elite is taken for granted in the willingness of the princess' attendant, called only Mbok [mother], to die in order to advance her love affair. The Adipati of Majapahit, a thoroughly unsympathetic character, is the only one to express any concern for the rakyat.

Viewing the deleted scenes, included at the end of the VCD version, reveals that the politics ended up on the digital equivalent of the cutting room floor. These include a scene showing Hang Tuah escaping from Pahang with Tun Teja, and asking her to eat something that will erase the love for him, which he had previously magically induced in order to capture her for Sultan Mahmud. Prefiguring Hang Tuah's betrayal of Gusti Puteri, the inclusion of this scene would have helped to complicate Hang Tuah's character, turning him from a wooden hero to the Sultan's procurer. More tellingly, another deleted scene invokes the classic showdown between Hang Tuah and Hang Jebat, the boyhood friend who rebels against the sultan in Hang Tuah's name. Hang Jebat appears to Hang Tuah, mired in the mangrove. At first Hang Tuah is overjoyed to see him returned from the dead, but they repeat their dispute over Jebat's treachery to the sultan. Jebat answers that he did it to avenge the sultan's unjust order to execute Hang Tuah. Hang Tuah answers that it was nevertheless treason, and kills Jebat all over again. That this scene, the crux of so much dispute in Malay literature and film, was edited out of Puteri Gunung Ledang shows the filmmakers' ambitions: to entertain with a love story, and not to trouble and/or bore the audience with a moral dilemma that still strikes at the heart of Malaysian political life. 
It might be said, however, that Puteri Gunung Ledang makes a liberal statement behind the scenes. Cast and crew were both multiracial and multinational, something to be remarked upon in the increasingly xenophobic (read: 'anti-Indonesian') and racialized climate of Malaysian domestic politics. Effendi Norwawi is Melanau; Tiara Jacquelina (born Jacqueline Eu) is of Burmese and Indonesian Chinese descent; the male lead M. Nasir is a Singapore Malay; Christine Hakim is an established Indonesian actress; Saw Teong Hin, the director and co-screenwriter is Malaysian Chinese; and so on. Resurgent Islam, in the form of the goateed and turbaned Demak warriors, does not come off well in the film, and nothing is made of the religious difference between Hang Tuah and Gusti Puteri. This, as well as Tiara Jacquelina's shoulderbaring and cleavage-suggesting costumes, may well have raised a few eyebrows among certain segments of the Malaysian public. It should be noted, though, that as in the 1961 film, Melaka here is a thoroughly Malay place - indeed, it looks rather like a kampung and not at all the cosmopolitan city described in Sejarah Melayu. The multi-ethnicity of the cast and crew and the overall secular outlook of the film can easily also be read as a reflection of the Malaysian elite under successive Barisan Nasional governments. While the New Economic Policy, introduced in 1971 and kept in place ever since, sought to allay racial tensions by transferring market share to Malays, it has also produced an oligarchy with members from all ethnic groups. Their price of entry into this exalted circle is delivering the loyalty of their communities to the ever-incumbent party. ${ }^{64}$ In the case of Puteri Gunung Ledang, there is nothing egalitarian about diversity. Just as the 1961 film may be seen as emblematic of its time - reflecting anxieties about the communist insurgency and about ideas of citizenship - so with the film of 2004, which unites a multi-ethnic cast and crew in the service of a bloated and vacuous spectacular that can well stand as celluloid testament to the excesses of Barisan Nasional-controlled Malaysia at the beginning of the new millennium.

\section{Conclusion}

The myth of a supernatural woman living on Gunung Ledang and associated with the royal house of Melaka, perhaps originally a chthonic or aquatic deity akin to Ratu Kidul in Java, underwent first a process of

64 See Edmund Terence Gomez and Jomo K. S. (1997), Malaysia's Political Economy: Politics, Patronage, Profits, Cambridge University Press, Cambridge. 
desacralization, so that by the sixteenth century it had dwindled to a colourful anecdote that nevertheless persistently attached itself to the figure of the last sultan. Next, over the far shorter time span that separates 1961 from 2004, it became depoliticized, so that even Puteri Gunung Ledang's allegorical or symbolic relationship to dynastic legitimacy was overlain by the gloss of an anodyne love romance. Of course, this is to recount the history of how she has been represented in the great tradition, the narratives produced by the centres of power, wealth and prestige. The saving irony is that in folk practice she retains some of her old significance and authority. Gunung Ledang is now part of a nature reserve, and while its biggest draw is the waterfall that attracts scores of Malaysian families at weekends and during school holidays, a small but significant following goes there for quite another purpose. On the other side of the mountain from the waterfall, past a cluster of orang asli homes, a road winds up to a telecommunications tower near the summit. On a Saturday in July 2007, it was possible to observe several white-clad men performing ritual ablutions by the side of this road, near the parked taxi that had carried them up from Melaka or Batu Pahat. Further on, more men were gathered outside Gua Nenek 'grandmother's cave', a clear reference to Puteri Gunung Ledang's incarnation as an old woman. Inside were offerings of flowers, incense and candles. Although no-one volunteered the information, it was clear that Gunung Ledang was still a supernaturally charged site, where one could go to petition the guardian female spirit for winning lottery numbers or other intercessions regarding one's health and prosperity. No doubt folk asceticism has also changed significantly over time, but the continued existence of petitioners for Puteri Gunung Ledang's favour is a salutary reminder of cultural continuity. 